\title{
Turning 'fate' into destiny by seizing a second chance at life
}

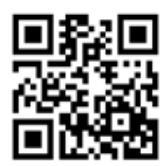

'What happened in the past is totally out of my control now.' With that simple yet life-giving affirmation, Daryl Brown, 27, legless in a wheelchair after jumping into the path of a London underground train on 29 September 2013, sums up the seachange in his world view.

As he slowly regained consciousness between the tracks with the bloodied stump of one leg lying beside his ear and rats scampering around his gaping wounds, the young university graduate had no idea how this barter with death would serve him. He prayed he'd die before the rescuers crawling under half the length of the train got to him, and he stifled agonised screams 'so as not to traumatise the families and little kids' alighting, blissfully unaware, above him. In hospital, whenever he regained any semblance of awareness, he feigned unconsciousness. A male nurse wheeling him on a gurney for an MRI scan made the first compassionate contact. 'He told me his name was Mads and said, "We've got you - we thought you weren't with us," squeezing my hand. I told him I'd been faking it - he didn't let go of my hand after that.'

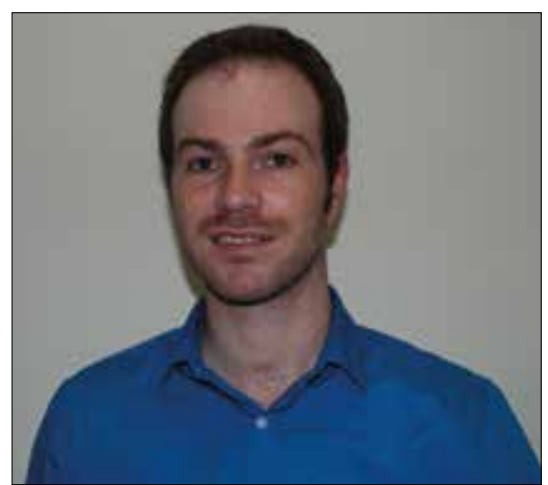

Daryl Brown. 


\section{Meticulously planned}

That autumn Sunday suicide bid - months in the planning, with a meticulously typed police advisory in his pocket (they didn't find it) and an explanatory e-mail sent to his mother's work computer for reading on Monday - was the first inadvertent step on Daryl's journey to admitting he was suffering from longstanding, untreated depression. Bullied for being gay (though he did not know he was) from his last year in primary school onwards, and confronting a fraught relationship between his parents at home, Daryl became inured to being pushed around in school passages and mocked in the bathrooms. II only then realised what being gay was. I didn't want to be gay if it was as awful as they were making it out to be. I thought depression was an excuse for not wanting to deal with my issues ... that I could overcome them myself. I couldn't think of anything a psychologist could say to make me feel better, it made no sense to me. I wish someone had come to give a talk at the school. I tried to solve it myself by getting involved in the church. I prayed to God to make me straight. Then I threw myself into my university work before finally deciding to "come out".

Daryl believed that if he lived who he really was' he would feel better, "but my mind and body had developed these negative habits. London became his 'last-ditch attempt' at getting his life right. He secured his master's degree and began his first romantic relationship with a 'good, kind and generous' partner, which ended in tears and deep depression six months later. 'I thought if he can't stay with me, no one will. I thought I was useless.' He set himself a 3-month deadline for death, organised a 'farewell' (as if he was returning to Cape Town) with his London friends, deactivated his Facebook account so nobody would twig that he hadn't returned home. His ex-boyfriend confessed to him that hed suffered from depression for three years and 'needed to deal with it himself'. 'His worries seemed more important than mine', recalls Daryl. He checked flights to Cape Town so that his deception would be complete if friends asked, and gave his landlord a month's notice. Sunday seemed a good day to end it all - it would cause the least commuter disruption and general public trauma. He shouldered his worldly possessions and headed off, settling down on an empty station bench 'completely disconnected from myself', playing Suduko on his cell phone. Then, in his own words, as the train finally approached, he 'just strolled off the platform.

\section{For the first time, psychotherapy} seemed like a credible solution. 'If people understood what I was going through, maybe there were ways of treating it. It was a huge relief for me to contemplate that this is was actually manageable that there was a medical reason for the way I felt and thought.'

\section{The long road back}

When he'd finally recovered sufficiently to begin psychotherapy, Daryl says he still tried to hide a lot. 'I thought if I tell them about my ex they'll judge him and who he is.' Then a psychologist at the Douglas Bader Rehabilitation Centre in London asked him 'all these incredibly incisive questions'.

'She seemed to know how depressed people think. She knew my most intimate thoughts and feelings. For the first time I realised I'm not crazy and I'm not alone. For the first time psychology seemed like a credible solution. If people understood what I was going through, maybe there were ways of treating it. It was a huge relief for me to contemplate that this was actually manageable - that there was a medical reason for the way I felt and thought. I used to feel like I was balancing this huge bucket of water on my head and it would come crashing down, showing that I can't deal with life.

Today Daryl is working in digital marketing in Cape Town, writing a daily blog, playing in a disabled volleyball team, and convinced that his suicide attempt was a blessing in disguise, prompting him into cognitive behavioural therapy (CBT), a modality he is convinced works, one of his favourite mindset-altering books being Eckhardt Tolle's The Power of Now. 'Sometimes I do feel that people feel sorry for me - like if I'm struggling to get cash at the check-out point, I still worry what the cashier will think of me - but now I'm slowly beginning to think it doesn't matter, I'll probably never see her again. I doubt that I'd be in therapy if it hadn't been for that suicide attempt, and nobody would have known about my depression. It was a cry for help, but served its purpose. I've learnt that there's no point in resisting. CBT has taught me that. I'm still very hard on myself and tell myself I have no right to feel sorry for myself because I did this to myself. But my friends point out that my disability is not the result of me or my actions, but because of an illness I have, which is depression.'

Daryl continues to work on his blog and inspire others labouring under the stigma of despair. He's about as 'out' as you can be when it comes to dealing with a subject that society still largely holds as taboo. Like the South African Depression and Anxiety Group that supports him and countless others, he doesn't believe that talking about his suicide bid will prompt copy-cat attempts. Instead it will probably help save those lives complicated by this hugely misunderstood condition.

\section{Chris Bateman}

chrisb@hmpg.co.za

S Afr Med J 2015;105(1):8-9.

DOI:10.7196/SAMJ.9167

SADAG contact details: (011) 234-4837, SMS 31393 ,

and www.sadag.org 